\title{
RELIGION AND MENDICITY IN SEVENTEENTH-CENTURY FRANCE
}

From the fifteenth through the seventeenth centuries, as absolutism emerged in its classic development, the lower classes of western Europe experienced great insecurity and hardship. The Hundred Years' War, the end of serfdom, the quickening of economic activity, the secular price advance, and the explosion of religious conflict shattered traditional social bonds, produced widespread destitution, and uprooted large numbers of peasants who took to the roads in a desperate nomadism. These vagrant populations, existing on theft, brigandage and, mainly, begging, evoked severe governmental repression which was to prove generally unpopular and, in the long run, ineffective. In seventeenth-century France certain private groups also were to take up the cause of repressing vagabondage through a systematic program of confinement in workhouses - a program which, while complementing royal policy, would draw its main inspiration from the ascetic spirituality of the French Counter Reformation. These bôpitaux généraux are of interest as concrete expressions of the convergence of social problems, absolutist political tendencies, and religious attitudes.

The first serious royal measures against vagrant mendicants had been promulgated in the fourteenth century in response to the Black Death and the resulting labor shortages. ${ }^{1}$ By the sixteenth century however the poor laws of the western European states had begun to reflect fear of socially surplus populations and a growing concern for

1 I.e., the Ordinance of 1350 , esp. title I, Des Mandians (Isambert, Recueil Générale des Anciennes Lois Françaises, IV, pp. 576-77), and in England, the Ordinance of Laborers of 1349. For the general problem see $\mathrm{C}$. Paultre, La répression de la mendicité et du vagabondage en France sous l'ancien régime, (Paris, 1906). Uncritical, diffuse in its presentation, this thesis in law is valuable for its copious documentation and abundant quotations from sources. Unfortunately there appears to be no work comparable to that of the Webbs on the continental poor laws and institutions in the early modern period. I have found their comparative discussions in English Poor Law History (London, 1927), Part I, and W. J. Ashley's An Introduction to English Economic History and Theory (New York, I 893), Part II, useful. 
public order and political stability. The chronic disorders of mendicants under the old regime were far more serious than the traditional violence of medieval beggardom. Although the corporative institutions of the old beggar kingdoms, with their fantastic nomenclatures and rituals, survived beyond the sixteenth century, they were engulfed by new destitute populations, less stable, less rooted, less accepted than medieval beggardom - huge aggregates which fluctuated in size with crop failures, wars, famines, and epidemics, and tended to concentrate in the larger towns.

During the fifteenth and sixteenth centuries the European monarchies, recognizing the inadequacy of traditional ecclesiastical poor relief, encouraged the established bourgeoisie to assume control of hospices and other charitable institutions of the Church. The municipal oligarchies were upholders of order; and in the early sixteenth century a number of important towns initiated new measures for the control and assistance of mendicants. ${ }^{1}$ The much discussed and imitated Aumône Générale of Lyon dates from this period. Like Lyon, most of the contemporary charités and bureaux des pawres (such as the Parisian Grand Bureau des Pauvres, established in 1544) sought to eliminate public begging by banishing "foreign" poor and regularly providing alms to native indigents. However, since these scattered projects had little effect on the rising numbers of vagrants, the monarchies sought to impose on all localities the responsibility for their own indigents. In France this tendency toward a general "poor law" culminated in the ordinances of Moulins ( 1566 ) and Blois (1579) which authorized local commissions of bourgeois to assume the administration of religious charitable foundations and to augment their revenues by parochial collections and tax levies. ${ }^{2}$ However, the urban oligarchies proved reluctant to devote revenues to the execution of the state's measures against mendicants - especially with the onset of the religious wars. Thus the municipalities, particularly the smaller ones, did little to impede the movement of their

1 J. L. Vives' De subventione pauperum (Bruges, I 526 ) was a plan for centralized support of the native poor requested and adopted by the town council of Bruges. It aroused wide interest in other municipalities. Luther's Ordinance for a Common Chest ( 1523 ) "supplied to the municipal authorities of many a city, not merely of Germany itself, but also of the Netherlands and elsewhere, a model for their dealings with the problem of the relief of destitution" (Webb, op. cit., p. 3I). For late medieval efforts by German towns to deal with the increase of mendicants, see G. Uhlhorn, Die Christliche Liebesthätigkeit im Mittelalter (Stuttgart, I 884), pp. 450-57. For details of the dissemination of such schemes, see Ashley, op. cit., esp. II, pp. 343, 346-49.

2 Moulins, art. 73, Blois, art. 65 (Isambert, Recueil, XIV, pp. 209, 399). The whole legislation is reviewed by F. von Reitzenstein, Die Armengesetzgebung Frankreichs, in: Jahrbuch für Gesetzgebung, Verwaltung und Volkswirtschaft im Deutschen Reich, ed. G. Schmoller, Vol. s (188I), esp. pp. 1 $25-128$. 
native poor to the larger cities, especially Paris, where the royal policy of grain provisionment acted as a powerful attraction to the destitute.

Faced with this influx of mendicants, hampered by a rudimentary administration, by its own niggardliness, by the passivity of the bourgeois oligarchies, and, not least, by the traditional popular toleration of begging, the monarchy resorted to increasingly harsh punishments for vagrant mendicants - forced work, banishment, whipping, branding, and the galleys - while subjecting them to new, extraordinary jurisdictions. ${ }^{1}$ Despite the fact that this repressive regime was only sporadically applied, it probably exerted a general inhibition on the free movement of the lower classes as a whole, thus contributing in some measure to those chronic patadoxes of the old regime: local labor shortages in the midst of socially surplus populations; insistent demands for cheap labor and panic fear of the masses of destitute. ${ }^{2}$ At the same time, the severity of the law itself tended to promote harsh, reprobating attitudes to the poor on the part of officials and bien pensants generally. The old distinction between the prevaricating (gueux valides, etc.) and the deserving poor (bons pauvres) - that is, between habitual beggars or vagabonds and victims of circumstance - was largely forgotten (except perhaps insofar as it could be applied to the aged, the infirm, and the declassed). Since the social and economic conditions which victimized the lower classes were irremediable and uncontrollable, and since the victims, the "deserving" poor, could not, by and large, be readily distinguished from confirmed beggars and vagabonds by their own habitual sobriety or work discipline, or separated from them by the crude administrative procedures of the time, the civic-minded legists and lovers of order tended to assimilate mendicity to vagabondage and vagabondage to criminality. Gradually bien pensant opinion learned to regard the masses of the destitute as offenders against morality, religion, and order (fainéants, gens oisifs, gens sans aveu). Such attitudes prepared the way for the severe and disciplinarian charities of the

1 R. Doucet, Les institutions de la France au XVIe siècle, (Paris, 1948), II, p. 523. Although the Tudors probably took the lead in these areas the French authorities were not far behind - in their pronouncements at any rate. Thus, for example, in 1635 (March 30) an ordinance of the civil lieutenant on the general police of Paris ordered all "vagabonds, even all apprentice barbers and tailors, and all others [without employment] and all debauched girls and women to find work within 24 hours, and if not, to leave this town and faubourgs of Paris, under summary penalty for men of being put on the chain and sent to the galleys, and for girls and women, of being whipped, shaved and banished in perpetuity" (Isambert, XVI, p. 424).

2 For a suggestive presentation of the labor problem under "early capitalism" see W. Sombart, Der Moderne Kapitalismus (Munich, I921), I, chap. 53, "Die Arbeiternot", esp. pp. 788,800 . 
seventeenth century, during which the quasi-penal confinement of indigents would emerge as a dominant motif.

By the early seventeenth century, most of the municipal charities of the preceding period were in decay - in part the effect of the religious wars which had also greatly reduced the policing activities of the state. Decades of civil turmoil now augmented demands for more effective measures against the disorders of the poor. In western Europe as a whole, emergent mercantilist ideas, which emphasized the need for a large and docile labor force at low wages, promoted the confinement of indigents in workhouses, houses of correction, "Bridewells", etc. - most of them places of centralized handicraft production. The numerous "general hospitals" founded in France during the seventeenth century were, in the broadest sense, mercantilist in tendency, if not inspiration. The old concern for public order is still there, no longer carried out merely in brutal and pointless bodily punishments, but now through the incarceration and forced labor of indigents. The term "hospital" had originally referred to the medieval almshouse, a shelter for the aged and infirm poor, the insane, orphans, pensioners, and pilgrims, as well as the sick. The "general hospital", on the other hand, was based on the idea of a voluntary or forced incarceration of groups considered socially marginal and potentially dangerous, particularly mendicants and vagrants. During the seventeenth century the medieval hospital or hospice was, in effect, superseded by the quasi-penal general hospital - half workhouse, half house of correction - the true ancestor of the modern prison. Uniting functions of police and charity, these institutions were devised to rationalize almsgiving and to discipline the poor - through a regimen of work and religious observance for inmates, and, for the vast majority remaining at large, through the deterrent effect of such incarceration. ${ }^{1}$ Although most frequently the work of zealous Catholics, whose motives were not those of mercantilist statesmen or police officials, the general hospitals carried forward the essentially repressive tendency of royal policy against the poor while compensating for its inadequacies and moderating its frank brutality.

The first serious effort along these lines was launched during the regency of Marie de Médicis. In those years Paris swarmed with vagabonds - military deserters, declassed nobles and bourgeois, unemployed artisans, and - most numerously, peasants driven from the land by war and famine. This floating population created the notorious anarchy of the Paris streets and a general insecurity of life and property after nightfall. Thus, in $\mathrm{I}_{\mathrm{I}} 2$, the government, very

${ }^{1}$ Sombart, op. cit., I, p. 82 I. 
likely at the urging of pious persons in the Paris Parlement and municipality, established three buildings, including Notre Dame de la Pitié, as a "general hospital" for the confinement of the native poor of the "ville, prévosté et vicomté de Paris". The Parlement decreed fines for almsgiving in the streets, the pillory for begging, and the galleys for those not submitting to incarceration. The statutes of the "Hôpital des Pauvres Enfermés" provided for a system of forced work, internal police, and sergens des pawres to round up indigents. ${ }^{1}$ Its inauguration resulted in a flight of vagabonds from Paris. However this success was short-lived and within a few years the city once again swarmed with beggars. By 16 I 8 the first attempt at a prison des paures was moribund, its decline hastened by an influx of refugees from the aristocratic disturbances in the provinces, the lack of funds, the general attachment to the old way of almsgiving, and by jurisdictional conflicts with the older Grand Bureau des Pauvres. The weakness and irresolution of the government compounded these difficulties. ${ }^{2}$

Despite the failure of the Hôpital des Pauvres Enfermés the notion that the maladministration of charity and the disorders of the poor could be overcome by incarceration gained wide currency. The anonymous Mémoire concernant les pauvres qu'on appelle enfermés, written in 1617 , criticized the weakness of the abortive project and enthusiastically argued proposals for a new hospital. The writer praises the workhouse of Amsterdam for the "harsh, vexatious, and difficult employments" which chasten the beggars and prostitutes. ${ }^{3}$ Their poverty is not apostolic, but a "veritable sewer of all kinds of villainies, evils, and frauds." 4 Hard work is justified by the Bible and idleness condemned as "mother and inventor of all evil." Together with these attitudes - which might by themselves pass for a generic Protestant piety stiffened by mercantilist interests - we find specifically French and Catholic elements. The poor are to be taught to respect the King and the magistrates and, above all, "to profess, practice, and live as true Christians and Catholics by attendance at divine service, sermons and catechisms, the frequentation of the holy sacraments of confession and communion, and other works of piety and devotion."6

1 Statuts Pour les Hospitaux des pauvres enfermez (Paris, I6II), arts. 19-21, 29-30; reproduced in M. L. Cimber \& F. Danjou, Archives Curieuses de l'histoire de France (Paris, 1837) Ire série, vol. I 5, pp. 273-81.

2 L. Lallemand, Histoire de la charité (Paris, 1910), IV, Pt. I, pp. 248-49; Paultre, op. cit., pp. 140-5 $x, 16 I-62$.

3 Mémoire concernant les pauvres... (as reproduced in Cimber \& Danjou, op. cit., Ire série, vol. 15, p. 248).

4 Ibid., p. 250.

5 Ibid., pp. 245, 268, $\quad$ Ibid., pp. 260, 269. 
The Mémoire was one of many seventeenth-century schemes for the confinement of the poor, at once penal, mercantilist, ${ }^{1}$ and religious in spirit. Applauded by the state and the municipalities, these schemes found their practical executors, for the most part, among the upper class zealots of the Counter-Reformation who dominated the famous Company of the Holy Sacrament.

\section{II}

The French Counter Reformation, which begins with the close of the Wars of Religion and reaches its apogee in the middle decades of the seventeenth century, was characterized by large-scale projects of charity, evangelization, and social discipline. Modern investigations have shown that many of these "good works", often attributed by hagiographic writers to the spontaneous zeal of individuals, were in fact organized and propagated by a powerful, secret group of devout laymen and priests whose influence radiated from Paris to all of France through a tightly controlled system of some sixty provincial branches, numerous and varied auxiliary groups, and prominent sympathizers. Founded toward the close of the $I_{2} 0^{\prime}$ 's by followers of Fran çois de Sales and Pierre de Bérulle - many of them, like the latter, tainted by opposition to Richelieu - the Company of the Holy Sacrament (Compagnie du Saint-Sacrement or, to its enemies, the "cabale des devots") achieved its greatest power in the decade of the Fronde, only to be exposed by the Jansenist crisis and officially suppressed by Mazarin. $^{2}$

Corresponding almost exactly to the "age of saints" in its life-span, the Company drew to itself such important religious figures as Vincent de Paul, Charles de Condren, Gaston de Renty, J.-J. Olier, and J.-B. Bossuet. Prominent aristocrats and officials such as Conti, Liancourt, Nemours, Schomberg, Séguier, Noailles, La MotteFénelon, Lamoignon, Morangis, and D'Argenson were also associated with the "cabale" - and, indeed, nobles and magistrates predominated

1 See ibid., pp. 263, 266.

2 The basic document on the Company is the Annales de la Compagnie du Saint-Sacrement... (Bibliothèque Nationale, ms. No. 14,489 , fonds français). I refer to the published edition by H. Beauchet-Filleau, Annales de la Compagnie du St-Sacrement par le Comte René de Voyer d'Argenson (Marseille, I 900). A comparison of Beauchet-Filleau's edition with a microfilm copy of the original manuscript has revealed only minor discrepancies.

Since the rediscovery of the "cabale des devots" in the late nineteenth century, a number of articles have appeared, and there are numerous references to it in modern literature on the period. The basic study of the Company's inner history and program remains Raoul Allier's La Compagnie du très Saint-Sacrement de l'autel: La "cabale des dévots" (Paris, 1902). Since the publication of the Annales a few volumes of other documents have appeared; these are cited where relevant, 
in the membership. ${ }^{1}$ Claiming to eschew political intrigue, this elite mounted a painstaking, relentless campaign for external order, a rational crusade against the "evils of the age." The "devots", many of them converts to the modish religiosity of the I630's and '40's, renounced the factious independence so recently endemic in their social milieu and expressed this renunciation in a holy private war on the pullulating chaos which they felt surrounded them. Their wealth, influence, propaganda, promoted missions, campaigns for teligious decorum and observance, religious and material care for famine victims, galley-convicts, etc. The Company's occult pressure played an important part in the condemnation of Jansenism, in the suppression of Tartuffe, and in the increasing erosion of Protestant liberties after 1630 . However, its distinctive role is seen in an energetic repression of popular licence: the rites of the journeymen's leagues (the compagnonnage), everyday blasphemy, illuminism, prostitution, etc. The term "désordre" is ubiquitous in the Company's Annales; usually it refers to the indiscipline and violence of the lower classes. Among the "disorders of the poor" none concerned the devots more than the widespread menace of mendicity and vagabondage, nor evoked more systematic schemes of repression. These schemes achieved their culminating expression in the great General Hospital of Paris (Hôpital Général des Pauvres), founded in 1656. The Holy Sacrament's campaign against the "evils of the age" reached its greatest intensity in the drive to confine mendicants and vagabonds - to incarcerate, as it were, disorder.

The Company of the Holy Sacrament began to look into the disorder of mendicity in 1631 , soon after its formation. ${ }^{2}$ Its rapidly expanding influence among the magistrates explains perhaps the Parlement's demand in $\mathrm{I}_{32}$ (arrêt of July ${ }_{1} 6$ ) for the "establishment of a general hospital in which the poor of all kinds and conditions could be conveniently lodged." 3 In 1633 the Company set itself the goal of "seeing established in Paris the same regulations [as were] followed in Lyon for the religious instruction and temporal care of mendicants."4 Originally created for temporary relief during famines and epidemics, then giving domiciliary assistance, the Aumône Générale of Lyon was forced by the mounting pressure of destitution in the early

1 The list of members of the main Parisian group has disappeared. I have reconstructed a roll of some 200 names from references in the Annales, death notices and other citations in the published correspondence.

2 Annales, p. 26.

3 Quoted in Lallemand, op. cit., Vol. IV, Pt. I, p. 250.

4 Annales, p. 4 I. 
seventeenth century to provide for the incarceration of native mendicants. In 1614 the directors of the Aumône established a general hospital (Notre Dame de la Charité) and by i 622 a large tract of land had been acquired and ten buildings raised. ${ }^{1}$ The ateliers of the Aumône Générale had engaged in silk manufacture, and this work was continued in the centralized "Charité". The regulations governing the labor of the inmates - chiefly winding (dévidage) - suggest a well-run phase of the Lyon silk industry, ${ }^{2}$ and given that industry's size and highly developed division of labor, the impression is doubtless correct. The apparent success of Lyon, the decay of the loosely administered Parisian Hopital des Pawves Enfermés, confirmed the dévots in their natural predisposition toward a severe internal discipline based on regular work and religious observance.

In any event, the plan of threatening the Parisian mendicants with confinement in a workhouse was not developed immediately. A generation elapsed between the original idea and the actual formation of the Company's "greatest project", the General Hospital of Paris. The confinement of indigents was to involve great expenses and require a long campaign of "excitation" and propaganda. In Paris a multitude of autonomous jurisdictions and charitable establishments survived from the past. Such obstacles to a unified general hospital were not overcome until the time of the Fronde.

During the 1640's, however, the Holy Sacrament had begun a serious campaign against mendicity in the provinces. For nearly a decade the devots had been establishing outposts in certain of the larger towns, including Lyon. Holding, like the state, that the disorders of the Parisian mendicants could not be suppressed until the poor throughout the kingdom were confined to their native localities, the central group promoted the organization of general hospitals (also known as maisons de charité) in a number of the larger towns. The Company's massive centralized correspondence served as a means of propaganda; the inner circle of officers which controlled it functioned also as a clearing house of information relating to the poor. In directing such efforts the devots acquired what was doubtless an unprecedented knowledge of existing hospitals and hospices. A letter to a provincial company describes the anarchy of hospital administration: some are under the authority of the grand almoner, some under the ordinaries, others are controlled by religious houses, by municipal officers, by lay patrons, etc. The lack of a uniform adminis-

1 Institution de l'Aumosne Générale (Lyon, I662), pp. I-7; A. Kleinclausz, Histoire de Lyon (Lyon, 1939-52), II, pp. 39-40.

2 Institution de l'Aumosne Générale, pp. 28-30. 
tration encourages irresponsibilities and abuses, especially in the management of landed endowments, which are leased at poor prices, allowed to be usurped by powerful neighbours, or made the subject of useless litigation. There are administrators and agents who appropriate sums for fictitious repairs of the fabric, and others who keep no accounts or, when they do, pass them on to collusive successors. Such revenue as is yielded by the hospital domains is often diverted to external uses - alms, preaching, etc. What remains does not necessarily go to the deserving poor, for there are administrators, magistrates, and other important personages of some towns who fill the hospital rolls with their domestics and dependents. Thus, more detailed information is necessary before the "plan of a general rule can be formulated..." The dévots of Marseille, to whom the letter is addressed, are requested to make a research of the number of hospitals in their diocese, their forms of administration, revenues, and charges, as well as of the abuses, disorders, and possible remedies which they remark during their visits. ${ }^{1}$

The "general rules" established in the provinces during the midseventeenth century were predominantly the work of the Company of the Holy Sacrament and its affiliates. Since most of these institutions fell into decay during the eighteenth century, relatively few documents survive. All of them appear to have aimed at the abolition of traditional alms and the rational control of charity through confinement of its recipients in a combined workhouse, asylum, and medical institution.

In 1639 the Parisian company commended the confrères of Marseille on their project of establishing a "house for enclosing and nourishing all the poor."' Emanuel Pachier, théologal of the cathedral, who is usually given credit for this work, ${ }^{3}$ had indeed been active in its behalf since 1622 , but without success. Only in 1639 , when, as one of the founding members of the Company in Marseille, he was able to enlist the support of his confrères - especially one Moustiers, a consul - did his efforts begin to bear fruit. The hospital (Notre Dame de la Charité) was built the next year; native mendicants were enclosed and begging was prohibited. Of the original ten directors of this general hospital, five were members of the Company. ${ }^{4}$ During its first years, Notre Dame de la Charité aroused the interest of a native

1 Letter of April 2, 1646 (R. Allier, La Compagnie du Très-Saint-Sacrement de l'autel à Marseille, Documents [Paris, I909], pp. 225-28).

2 A. Rébelliau, La Compagnie secrète du Saint-Sacrement. Lettres du groupe Parisien au groupe Marseillais, $1632-1662$ (Paris, 1908 ), p. 13.

3 E.g., Paultre, op. cit., p. 260.

4 Allier, Marseille, p. 5 In.; Paultre, op. cit., p. 260. 
of Aix, Gaspard de Simiane, chevalier de la Coste - a zealot who inspired the founding of most of the Company's branches in Provence. His requests for information on methods of raising funds, number and work of inmates, and the choice of administrators reveal the Company of Aix working for the establishment of their own "Charite".. Some years later, the Parisian devots noted with pleasure the founding of a general hospital by their confrères at Angoulême. ${ }^{2}$ In 1642 the Company's Annales tell of a general hospital established by the Company of Orléans. ${ }^{3}$ Five years later, the devots of Limoges began their project of incarcerating all mendicants who were to be "employed at works and manufactures..."4 In Grenoble, where the idea had been mooted since 1627 , the Company of the Holy Sacrament succeeded in consolidating the existing charitable and medical institutions and incarcerating the poor in $166 \mathrm{I}$. The founding of this general hospital took two years, during which the members agitated in the town council for the imposition of a poor tax, engaged monks and nuns to staff the hospital, and prepared the minds of the bishop (Scarron) and the governor (Lesdiguières) and public opinion generally for the novelty. ${ }^{5}$

The plan for the establishment and administration of the general hospital of Toulouse has survived. Entitled L'Aumône Générale, ${ }^{6}$ it is a project of confinement, apparently freely adapted from the regulations of Lyon and probably written up for oral delivery to a small group. Although L'Aumône Générale is anonymous, it unquestionably

1 Allier, Marseille, pp. 149n., i 50.

2 Annales, p. 120.

8 Ibid., p. 87 .

4. Aulagne, La réforme catholique du dixseptième siècle dans le diocèse de Limoges (Paris, 1908), pp. $558-59$.

5 Lagier, La Compagnie du St.-Sacrement de Grenoble, in: Bulletin de la Société d'Archéologie de la Drome, L (1916), pp. I55-56.

In Lyon, although the renowned Notre Dame de la Charité was considerably older than the Company, at least six of the rectors of the Aumône Générale appear in the membership roll of the local dévots (Guigue, op. cit., pp. 70, 80, 81, 87, 89, 90).

By the middle of the eighteenth century there were considerably more than Ioo general hospitals. Of the oldest of these (i.e., the ones founded in the mid-seventeenth century, before the activity of the Jesuits in this field) a score or more were established in towns where there already existed branches of the Holy Sacrament. For example, in Poitiers, the Company was established in $\mathrm{I}_{442}$, discussions on a hospital began two years later, and 200 poor were enclosed in 1657 (Paultre, op. cit., p. 304). In Noyon the dévots were organized in 1656 ; letters patent for a general hospital were issued in the following year (Lallemand, op. cit., IV, pt. I, p. 26I). In Dijon, a chapter of the Company and a general hospital were both established in I 643 (Paultre, op. cit., p. 292).

- Reproduced in A.Auguste, La Compagnie du Saint-Sacrement à Toulouse; Notes et Documents (Paris, 1913), pp. 47-59. 
emanated from the Holy Sacrament of Toulouse." The "Compagnie" is mentioned several times, and many of the individuals active in carrying out its proposals have been identified as members of the Holy Sacrament. ${ }^{2}$ In fact there is no doubt that it was under the influence of the Company of the Holy Sacrament that the Hospital of Saint Sebastian de la Grave for the pestiferous poor was transformed about the middle of the seventeenth century into a general hospital where all indigents could be supported and made to work so as to combat mendicity. ${ }^{3}$

The Aumône Générale begins with a vivid description of the mendicant poor. Traditional alms, it is held, do more harm than good by supporting

"une pepinière de feneants de taverniers de gourmants, de sales et vilains, de larrons et voleurs, et un mestier tres dommageable a la republique."4

Moral disorders among the poor include mock weddings and casual marriages, the corruption of peasant girls by procurers or, what is worse, by the influence of mendicant Huguenots, libettines, and gypsies. Typically improvident is the way in which they spend all their money on newly picked fruits, "eating them green and dry, like beasts." From this comes their sickness, hospitals full of dysentery, streets full of infection, ordure everywhere. "The poor, who by birth should serve the rich", are worthless after having passed their tenderest youth in idleness, beggary, and libertinage, and when they do occasionally take service, usually provoke their masters to oaths and blasphemies. ${ }^{5}$

The devots, who hoped to secure an existing hospital building from the municipality, set about raising the necessary funds for the actual maintenance of the poor by organizing a collection (known as the method à la capucine). The Aumône Générale reflects the sober practicality of the Holy Sacrament in such enterprises: the collection day should be made known in advance so that alms, whether of money or food, will be at hand; the collectors should not be rich persons but those who, knowing at first hand the disorders caused by the poor,

\footnotetext{
1 Auguste, op. cit., pp. 4I-45. passim.

3 Auguste, op. cit., p. 39

4 Ibid., p. 47.

5 Ibid., pp. 48-9.
}

2 Allier, Une Société Secrète au XVII Siècle: la Compagnie du Très Saint Sacrement à Toulouse (Paris, 1914), pp. 14-18. This was done by looking for the names of well-disposed capitouls, parlementaires, and cathedral clergy, as well as for directors of the General Hospital in the Parisian company's printed obituary circulars. See Rébelliau, op. cit., 
have sought to remedy them - presumably the members. Rounds are to be made by different collectors according to locality - faubourg or ville - as well as professional and social position - e.g., bourgeois and merchants are to be solicited by two bourgeois and a priest; in addition, a member of the "Company" is to have the responsibility for requesting alms of any great lay or ecclesiastical lords arriving in Toulouse. The fact that all special collections (save those by mendicant friars) were to be merged into a general collection would encourage larger contributions from those anxious to avoid the importunities of the poor. ${ }^{1}$

Once enclosed, the poor were to be separated into various groups - married people, aged men, aged women, young boys, girls, and the pestiferous poor and hermits if any - each occupying a different quarter of the hospital. The provision of work for those physically capable would serve to separate the vagabonds and professional beggars from the "true" poor - girls set to spinning and boys to some craft. The smallest children would be kept busy "in order to accustom them to work..., and so that their minds would be formed to better serve God and men... they might be taught reading." A dozen hand carts ("charriotz") were to be made so that the "big youths" of the hospital might be kept busy cleaning the streets - under the supervision of the town guard. Finally, the advantage was pointed out of having all the poor concentrated in two institutions - the Grand Hôpital (for the sick) and the Hospital de la Grave (the General Hospital) for the rest of the mendicants - since individuals desirous of helping them need not disburse their alms to professional beggars, while the shame and necessity of invalid or "decent" poor unable to enter either hospital would be better known. ${ }^{2}$

The priest Arnaud Baric and several other members of the Company were deputed to win over the archbishop and the town-councillors ("MM. les Capitouls") to the project. ${ }^{3}$ Thus, the old Hospital de la Grave was restored by the municipality and given over to the incarceration of mendicants, which began in 1647 . The permanent effects of this institution are difficult to ascertain, although one can say of it, as of all the general hospitals, that the intended goal, abolition of mendicity, was not attained. ${ }^{4}$ Probabably before the obduracy of the mendicant disorder could become fully clear, the General

\footnotetext{
1 Ibid., pp. 50-5I, 55, 58 .

2 Ibid., pp. 54, 56, 57.

3 Which he had probably drawn up. See Auguste, op. cit., pp. 41, 75; but also, Allier, Toulouse, p. 20.

4 Thus in $171_{3}$ it was deemed necessary to create a "Bureau of Charity" to press for the confinement of mendicants (Paultre, op. cit., p. 278).
} 
Hospital was undermined by religious controversy. During the I640's some groups within the Company of the Holy Sacrament had begun to show Jansenist proclivities. Ultimately all overt espousers of the "new opinions" were purged from the main company, which was thus able to play an important part in the struggle against Port Royal in the I650's. Nevertheless, a certain Jansenizing tendency survived among the devots, and the purge itself was not uniformly successful. Within the Toulousan group the new opinions were apparently in the ascendant. 'Toward the close of the I650's, the Company there became something of a Jansenist circle and many of its activities were curbed by the hostility of Jesuit sympathizers and auxiliaries. During these years the General Hospital did not flourish. Its registers break off in $166_{3}$, and when they are resumed in 1681 they seem to refer to a totally reconstituted hospital. By that time the Holy Sacrament of Toulouse had been dead for at least a decade. ${ }^{1}$

\section{III}

Up to the time of the Toulousan devots' Jansenist entanglements, their General Hospital had the powerful support of the Parisian Company. It is likely that the Queen Regent's letter to the Capitouls in 1647 , praising the new foundation as their work, was written at the instigation of a highly placed member, for Anne of Austria was susceptible to the Company's influence; ${ }^{2}$ and the Company, in turn, was doubtless prepared to see others given public credit, provided the objects of its occult activity prospered. Again, when Gabriel de Ciron, in Paris as a deputy to the Assembly of the Clergy of I655-57, sent the statutes of the newly organized General Hospital of Paris to his fellow devots in Toulouse, to be adapted to their rules, and when, in 16,8 , he secured letters patent for the General Hospital of Toulouse, the collaboration of the central group is plain. ${ }^{3}$

The Parisian General Hospital, established in 16,6 , was considered by the dévots "the greatest and strongest of their enterprises," and D'Argenson, composer of the Annales, writing in the 1690's, thought

1 Auguste, op. cit., p. 72.

2 Ibid., pp. 72-73. "This pious Princess knew of the great good which the Company had procured in the Kingdom; she therefore favored it powerfully during her Regency; she frequently commended herself to the prayers of the honorable people who composed it and who were honored by her friendship" (Annales, p. 179). "This pious Princess knew the most important members" (Annales, p. 205).

3 Auguste, op. cit., pp. 98-100. Especially since the Annales refer to Ciron's participation in another favorite cause of the Holy Sacrament, the war against the compagnonnage during the same period (November I655) (Annales, p. I55). 
of it as one of the surviving works which best embodied the spirit of the defunct Company. ${ }^{1}$ Its establishment was prepared by the social violence of the Fronde.

The early I650's probably mark the high point of popular suffering under the old regime. ${ }^{2}$ The depredations and atrocities visited on the peasantry by the rival armies of the princes produced a great crisis of destitution in Paris. According to contemporary estimates the city's mendicant population stood at 10,000 in 1610 ; by the end of the Fronde the number had risen to 40,000 (of a total population of some $425,000){ }^{3}$ The mass of refugees spilled over into the environs of Paris. In June 1652 the Company of the Holy Sacrament began to assist the destitute, assembling them in the Cemetary of St. Hippolyte, where they were given alms and religious instruction. As always, the Company eschewed purely secular charity and gave assistance only "when the glory of God and the interest of religion" were visibly served. ${ }^{4}$ The drain on the Company's resources was nevertheless unprecedented. In order to rationalize the allocation of relief and to facilitate contributions, the dévots organized a Charitable Storehouse (Magasin Général Charitable). Established in 1652 , it continued to function for several years, probably with the support of the Holy Sacrament's "front" groups in Paris, the "parochial charitable companies." With the end of the Fronde, however, the dévots turned from temporary charities to a "permanent" solution of the disorder of mendicity - incarceration.

In 1653 , shortly after the establishment of the first parochial charitable companies, the Holy Sacrament relieved Christophe du PlessisMontbard, one of its most active workers, of his other duties so that he might devote himself exclusively to the work of a "great hospital for the confinement of mendicants." 6 Three years later, Du Plessis

1 Rébelliau, op. cit., p. 98 ; Annales, p. 239.

2 A. Feillet, La misère au temps de la Fronde et Saint Vincent de Paul (Paris, I 886), esp. pp. $125-53,177-203,253-73,357-64,402-23,463-75$. J. Jacquart, La Fronde des Princes dans la Région parisienne et ses conséquences matérielles, in: Revue d'histoire moderne et contemporaine, VII (Oct.-Dec. 1960), pp. 257-90.

3 E. Levasseur, La population française (Paris, 1889-92), III, p. I 7 .

4 Annales, pp. $120,127$.

5 Ibid., pp. 132, iso.

- Annales, p. 136. Du Plessis-Montbard was an avocat au parlement. Certain "principal magistrates" are usually credited with having met during the I640's to lay the basis of the General Hospital (H. Sauval, Histoire et Recherches des antiquités de la ville de Paris [Paris, 1724] I, p. 526, followed, among others, by Paultre, op. cit., pp. I 54-55, who was apparently ignorant of the Company of the Holy Sacrament). The first president Pomponne de Bellièvre is also frequently cited as leader of the project, although without any substantiation beyond contempotary allusions which associated him with the "rêverie des 
reported that letters patent for the General Hospital had been verified and directors sworn in by the Parlement; he commended the great work to the prayers and alms of the Company, which, he added, "conceived the idea first [and] had laid the foundations by means of individuals designated for the task." 1 This report was purely formal. The Holy Sacrament or at least its directing committee had organized the General Hospital: Antoine Godeau, former libertine poet, but now bishop of Vence, preached at its opening, and another member, Louis Abelly, an associate of Vincent de Paul, became the first rector. A royal edict of May 4, I6,6, named twenty-six perpetual directors; twelve of them were members of the Company of the Holy Sacrament. ${ }^{2}$

The government made over to the administration of the Hôpital Général des Pauvres a number of existing properties and institutions, including Pitié, Salpêtrière, Bicêtre, La Savonnerie, and Scipion. Of these, only the first had been explicitly established for the repression of mendicity; but all of them were in fact loosely run charities which harbored a great variety of indigents - infirm aged, physically diseased, insane, pregnant and nursing women, some prostitutes, foundlings and orphans. ${ }^{3}$ The royal decree of foundation proposed to transform this congeries of mild and somnolent institutions into a vast maison de force "where the mendicant poor, sound and infirm, of both sexes could be confined and employed at manufactures and other work, according to their capacity."4

A year was spent in the preparation of this plan. The dévots and their sympathizers in the Paris clergy sought to win public approval in sermons and pamphlets. Although the General Hospital was to receive the revenue of certain fines, taxes on legal communities in Paris, and of an octroi on wine, voluntary contributions were seen as an important source of income. By the royal edict the legal representation of the mendicant poor of the prévôté of Paris devolved on the directors of the General Hospital, which thus became the recipient of all undesignated benefactions. ${ }^{5}$

devots" and the fact that he contributed large sums to the Hospital (e.g., Lallemand, op. cit. IV, pt. I, p. 254). 'The Company of the Holy Sacrament was very well represented in the upper Paris magistrature; but beyond this its initiative is clear from the Annales, which recount the establishment of a committee of eight to work for the General Hospital as early as 1636 (p. 26).

1 Annales, p. 163 (Sept. 28, 1656 ).

Ibid., p. 170; Allier, Cabale, pp. 65, 26n.

3 H. Sauval, Antiquités de Paris, I, pp. 525-36.

4 Edit du Roi (April, 1696) art. I (as contained in l'Hospital Général de Paris [Paris, 1676], p. 19).

5 Edit du Roi, arts. 31, 35, 38, 39, 40, 41. A. Husson, Etude sur les hôpitaux (Paris, 1862), pp. 515-16. L. Parturier, L'assistance à Paris sous l'ancien régime et pendant la Revolution(Paris, 1897), p. I4I. 
The actual incarceration of indigents began in May 1657. The directors had been given "full power, authority, cognizance, jurisdiction, police, correction, and punishment" over all the mendicant poor of Paris and its environs. ${ }^{1}$ Their initial steps seemed in earnest. A company of "archers of the poor" was enlisted to pursue and seize recalcitrant beggars. Direct almsgiving as well as begging were prohibited. For the latter offense whipping was decreed, the galleys in cases of recidivism. ${ }^{2}$ It would appear that for a time the Paris streets were free of the usual throngs of mendicants. ${ }^{3}$

In its first year the General Hospital harbored some 6,000 poor. ${ }^{4}$ The great majority of these had entered voluntarily and was made up chiefly of the aged, infirm, and orphaned. Strictly speaking, actual forced confinement was limited to a few hundred "sturdy beggars" professionals and recalcitrants who were held in Bicêtre for a week or two, then released. However, the new institution as a whole was unquestionably penal in spirit. Those who hesitated to enter "voluntarily" could expect harsh new measures against mendicity. On the other hand, the institutional complex of the Hopital Général des Pauvres with its imposing, somewhat isolated buildings, vast and regular (Salpêtrière), fortess-like (Bicêtre), its special police and impersonal bureaucracy, had a forbidding character, quite unlike that of a place of refuge and assistance. Although the medieval reverence for poverty might persist among some, the old loving and careless care of the poor was now evident only in occasional acts of selfa-bnegation by charitable dévots, or in the language of spiritual writings - not in privileged or comfortable accommodations. Given the conscious concern with the "plague" of mendicity and the fact that the General Hospital could harbor only a small fraction of the mendicant poor, its uninviting character was inevitable - as was a certain arbitrariness in the selection of inmates. The internal regime suggests a prison rather than an almshouse. The founding edict empowered the directors to punish with "whipping posts, pillories, prisons, and dungeons in the said General Hospital and places depending on it, as they deem fit, without appeal from the ordinances made by them within the said Hospital." The rules covering the inmates' daily life convey a rigorous and dour precision. There was a careful regulation of the hours "of rising and retiring, of prayers, of

1 Art. 12 of founding edict(Edit du Roi, in Hosp. Gén. de Paris, p. 22).

2 Arts. 9, 14, 18, 22 (op. cit., p. 19).

${ }^{3}$ See Lallemand, op. cít., IV, pt. I, p. $258 \mathrm{n}$. for examples of contemporary reactions.

4 Paultre, op. cit., p. 185.

5 Edit du Roi (Apr. 1656), art. 13. 
work, of meals..." The inmates were to be "clothed in grey robes and caps and have each on their robes a general mark and a particular number." An elaborate system of workshops was instituted in which the poor were engaged in brewing, milling, spinning, weaving, and (chiefly) knitting. The avowed purpose of this industrial regimen was not the support of the Hospital (indeed, the workshops proved costly and had to be subsidized) but rather its presumed disciplinary and moralizing effects on the poor. ${ }^{2}$ Those vigorous mendicants who refused to work at a trade were sent to Bicêtre, where they were put to work at stone quarrying, hod carrying, and terracing projects.

The statutes and regulations of the General Hospital disclose, therefore, a prison des pawres, a house of correction which imposed a severe and exact discipline on its charges and served more as a threat than as a haven to the lower-class mendicants remaining at large. In its immediate effects, this institution, like so many other projects of the devots, dovetailed with the emerging absolutist policies of the government. The Company's scheme of incarceration anticipated and to some extent prepared the royal measures of the 1660's and 1670's for the internal security of Paris. The creation of the new office of lieutenant of police, the introduction of street lighting and of a fire service, and the abolition of autonomous jurisdictions, checked the most visible disorders and produced an unprecedented security in public places. 'The Company's own campaign of repression contributed to this regime by isolating the mendicants. Although its propaganda was incapable of turning public opinion against private almsgiving, the threat of banishment or incarceration, brought home by the archers of the poor, increased the desperation and violence of the mendicants who remained at large. They had begun to appear in mobs and "did not recoil from robbery and murder." 3 Thus the way was cleared for the dramatic intervention of the state.

With the beginning of Louis XIV's personal rule, the laws against sturdy beggars and vagabonds were harshly enforced and the galley benches were "filled in large part by vagabonds rounded up by the police in Paris and in the provinces."4 This policy, which was warmly supported by Colbert, marked the culmination of the monarchy's long efforts to assimilate mendicity, with its sanctions in tradition and

\footnotetext{
1 "Règlement que le roy veut estre observé pour l'Hospital Général de Paris," arts. xvii and xxiv (in L'Hospital Général de Paris).

2 Paultre, op. cit., pp. 185-89; also "Règlement" of 1656 , art. xix.

3 A. Monnier, Histoire de l'assistance publique dans les temps anciens et modernes (Paris, 1866), p. 351.

4 E. Lavisse, Histoire de France, VII, pt. I, p. 308.
} 
religion, to vagrancy and criminality. ${ }^{1}$ Although the causes of destitution were hardly touched, severe repression discouraged its more disorderly manifestations and led to the destruction of the surviving remnants of the old corporative beggardom. ${ }^{2}$ The most notorious of these was the cour des miracles near the Porte St.-Denis. ${ }^{3}$ This resort of the Parisian underworld, fortress-like, accessible only to the initiate, enjoyed a kind of semiofficial tolerance down to the 1660's. Its destruction (in a sense analogous to the abolition of the seigneurial jurisdictions of Paris in 1674 ) was carried out by the first lieutenant of police of Paris, Nicolas de la Reynie, in 1667.4 After his commissaries and soldiers had been repulsed by volleys of stones, La Reynie himself led a force consisting of I 90 soldiers of the watch, others of the marshalcy, and a squad of sappers, which succeeded in forcing the gates and razing this "sad vestige of the barbarism of another age." 5

Such coercive measures were widely detested in the seventeenth century. The General Hospital's "archers of the poor" encountered a "brutally manifested repugnance on the part of the people", and in 1659 efforts to round up beggars resulted in eight armed riots. ${ }^{6}$ Even within the leadership of the Counter-Reformation, generally committed as it was to a systematic and hence, inevitably impersonal attack on the "evils of the age", these popular attitudes were echoed in a certain tacit refusal to support the large-scale confinement of the poor. Vincent de Paul was one of the least "extraordinary" and most "human" figures among the devots. He had collaborated with them in improving the condition of galley convicts and in charitable and religious missions to the war-ravaged countryside. However, nowhere

1 The preamble to the Edict of August, 1661 , against mendicants announced that the mendicity of able-bodied persons had "always been so odious to all peoples that none have been found willing to suffer it; and all states have ordained punishments for those who wish to live in idleness without contributing something of their work or their industry to the public" (Isambert, Recueil, XVIII, s).

2 "Since the establishment of the General Hospital, the Courts of miracles...no longer depend on the Grand Coesre, [and] daily his subjects and officers are removed and imprisoned in Bicêtre and in La Salpêtrière" (Sauval, Antiquités de Paris, I, 514). See also Paultre, op. cit., p. 3 Io. - "Coesre (grand). Mot d'argot. Chef des gueux." Huguet, Dictionnaire de la langue française du $\mathrm{I} 6$ me siècle.

${ }^{3}$ Between the rue Montorgueil and the rue Saint-Denis (Sauval, op. cit., I, pp. 5 I I-I 2).

4 It is of passing interest to note that La Reynie's successor, Marc-René de Voyer de Paulmy d'Argenson, was the son of the Holy Sacrament's annalist.

5 P. Clément, La Police sous Louis XIV (Paris, I 866), pp. 134-35.

- Monnier, op. cit., p. 350 . An ordinance of 1669 (Oct. 10) attributed the large number of mendicants in the streets to the general hostility to the archers of the General Hospital, who had difficulty in arresting beggars "because of the protection given them by the domestics of persons of quality, by bourgeois, artisans, soldiers, and the common people..." (quoted in Paultre, op. cit., pp. 195-96). 
did he better fit the image of a people's saint than in his attitude to the General Hospital. A member of the Company of the Holy Sacrament, he had made over to its nascent project the buildings of Bicêtre and Salpêtrière - previously attributed to his own charities by the court. Nevertheless, the size of the proposed institution disturbed him and he began to question the ideas of banishment of the "foreign" poor and of forced confinement. It is said that he knew of the evils of the English houses of correction from the reports of his missionaries. Thus, uncertain "if the Good Lord wills it", he declined to have the direction of the General Hospital confided to his Lazarists. Soon after, his disciple and biographer, Louis Abelly, a member of the Holy Sacrament, resigned as rector. ${ }^{1}$

Vincent de Paul's toleration of mendicity reflected a simple Christian meliorism, very close to popular attitudes and like them opposed to bureaucratized control of indigents. These attitudes, involving as they did an acceptance of the everyday realities of the "world", were alien to the spirit of the rational crusade, and to the intention of the General Hospital. Before long these realities and the social order which perpetuated them presented their claims on the General Hospital.

Ostensibly a work of charity and assistance, the original General Hospital was fundamentally disciplinarian and penal in spirit. Within a few years, however, the need for emergency relief had begun to overshadow the Hospital's repressive purposes. During the great famine of 1662 , the directors were obliged to admit some 3,000 "foreign" poor from the provinces. A brochure published on behalf of the directors that year inadvertently reflects the general tendency of the age to mix charity with police measures on a practical level:

“... having seen this autumn a great number of neighbouring places and a few more distant provinces, in order to satisfy the public and their own obligations, they resolved to enclose all of those found mendicant, with a view both to help them and also, by this strictness, to prevent others from coming through the natural fear of being locked up."2

\footnotetext{
1 Oct. 10, 1657. On Vincent de Paul's reluctance to associate himself with the Greneral Hospital see his letters to the duchess d'Aiguillon, in P. Coste, (Ed.), Saint Vincent de Paul: Correspondance, Entretiens, Documents (Paris, 1920-25), VI, PP. 245, 250-51, 257. Coste, in Le grand saint du grand siècle: Monsieur Vincent (Paris, I932), II, pp. 501-507, describes Vincent de Paul's disapproval of the General Hospital but avoids connecting this disapproval to his refusal to supply priests. See, however, Lallemand, op. cit., IV, pt. I, Pp. 254-55, and Feillet, op. cit., Pp. 522-23.

2 Quoted in Paultre, op. cit., p. 193.
} 
This hope came to nothing. Moreover, the general hospitals in other towns, usually weak administratively and financially, far from immobilizing and supporting their own destitute, probably forced an even greater number of paupers into vagabondage through the stricter police measures which the very existence of such institutions often inspired. Nevertheless there were renewed demands for the confinement of "foreign" mendicants in their local parishes, and a royal edict (1662) which ordered the creation of hospitals "for the native poor ... of those towns without such institutions." "This general poor law ultimately led to the formation of some new "bureaux de charité", ${ }^{2}$ but as concerned the number of mendicants in Paris it was to have no more effect than its predecessors. By the I670's the General Hospital maintained around I0,000 poor, ${ }^{3}$ many of them from the provinces. The pressure of indigents, intermittent but mounting, had produced a rapid change in the original character of the "prison des pauvres": its repressive function was attenuated, and the drive for social discipline became secondary to the need for elementary relief. ${ }^{4}$

Although the disorders of the poor had come under better control after the Fronde, the problem of mass destitution was never to be solved by the old regime; $;$ indeed, the number of mendicants increased during the last century of its existence. Since the means of relief were trifling against these seas of destitution, the administration of charity

1 Edict of June I662 (Isambert, XVIII, pp. I8-19). The confinement of the "foreign" poor in the General Hospital of Paris was, however, authorized by a governmental decree: "The streets and churches are crowded with them, and mendicity has become as common as it was before the establishment of the General Hospital. [The Directors of the General Hospital] propose to do all in their power to shelter the poor from the countryside and to provide their subsistence...until the beginning of the harvest..." (quoted in P. Bondois, La disette de r662, in: Revue d'histoire économique et sociale, I 2th yr. [1924], p. 105).

2 Around the turn of the eighteenth century, and chiefly in the south of France. These "charités" were largely the work of the itinerant Jesuits Chaurand, Guevarre, and Dunod. See C. Joret, Le P. Guevarre et les Bureaux de Charité au XVIIIe siècle, in: Annales du Midi, I (1889), pp. 340-93; and Paultre, op. cit., pp. 21 9-304.

3 Paultre, op. cit., p. 206.

* A lettre de cachet of Oct. 10, 1669, in execution of the ordinance of that date against mendicity, complains that the directors of the General Hospital release vagrant mendicants too readily and provides that patwres valides caught begging a second time be permanently incarcerated (reproduced in L'Hospital Général de Paris, pp. I08-IO9).

5 Bondois, art. cit., relates the famine of 1662 to the "shackles of the feudal system" which the old regime was incapable of loosing (p. I i 7 ). "Almost the only remedies... for the profound misery of the people...were enterprises of 'charity' which had perhaps a high moral value but which, despite the object of social pacification which they sought and generally attained ... could not really palliate the irremediable evils caused by the lack of basic subsistence" (p. 57). 
became, like that of all privileges under the old regime, lax and corrupt. In the General Hospital of Paris, although a monastic schedule of prayers, masses, and catechisms was still enforced in the eighteenth century, the workshops fell into desuetude. Indigent families, excluded by the original edict, had been admitted soon after the foundation. Later, the dormitories came to harbor not only the destitute, the insane, the feeble, and the immoral as such, but increasingly, personal dependents and clients of the directors. ${ }^{1}$ The General Hospital thus reverted to a confusion of indolent refuges, schools, prisons, infirmaries, orphanages and asylums, which retained nonetheless a harsh, penal reputation.

Nevertheless, during the eighteenth century new attitudes to mendicity and destitution were stirring among the educated classes. The repression of mendicity came to be seen as the work of the "legislator", undertaken in the spirit of "political economy" and secular reform, guided by the notion of a rising social demand for labor. The crusades of secretive zealots for "order" affronted the temper of the age, and their general hospitals, their melange of police and charity, were attacked as useless and, indeed, harmful. Vagrancy and habitual idleness might now be punished, but only for the rational purpose of educating the faineant to the advantages of "free" labor. ${ }^{2}$ Frustrated in practice, the physiocrats and the humanitarian reformers stirred powerful currents of opinion which ultimately shaped the principles of the Revolutionary poor laws: rejection of the large workhouse or its transformation into a full-fledged prison for the professional vagrant, who was now more precisely defined in law, and in practice almost fully assimilated to criminal status; for the poor citizen, regular assistance and public works, authorized and controlled by the national government, without religious tests, or the threat of confinement or of banishment to " native" provinces. ${ }^{3}$

During the seventeenth century these principles, and the thought pattern which underlay them of construing social experience in terms of mechanisms, might have been appreciated by isolated individuals under the influence of mercantilist ideas. However, the repertory of optimistic assumptions which made the idea of rational, public philanthropy acceptable and familiar to the educated classes during the Enlightenment - natural and social harmony, utilitarianism, progress - were alien and, indeed, unknown to the "saints bommes" and "gens de bien" of the Counter-Reformation. The upper-class zealots of the Catholic reconquest were bound to emphasize the

1 Paultre, op. cit., pp. 197-99, 203-204.

2 C. Bloch, L'Assistance et l'Etat en France à la veille de la Révolution (Paris, I 908), p. I6I,

3 Ibid., pp. 43 I-49. 
effects of destitution rather than its causes, and to deplore the loosening or weakening of social bonds rather than the social order itself. In the introduction to the collection of documents known as L'Hospital Général de Paris, the anonymous writer, clearly sympathetic toward the defunct Company of the Holy Sacrament, if not himself a former member, recalls the great increase of mendicants which led to the tormation of the General Hospital:

"The numbers grew daily, and finally formed, as it were, an independent people which knew no law nor religion, nor superior, nor police; impiety, sensuality, libertinage were all that governed them; most of the assassinations, thefts, and violence by day and night were the work of their hands,... All of these prodigious disorders continued unabated until I 640 , without giving rise to much reflection: But then a few individuals of great virtue were touched by the deplorable state of the souls of these unhappy Christians. They were not, nevertheless, objects of compassion because of their bodies, however afflicted they may have appeared; For they found in the charities of Peoples more than was necessary to satisfy their needs and even their debauches; but their souls, sunk in a total ignorance of our mysteries and in the extreme corruption of their habits, gave ample reason for pain to the people animated by zeal for the salvation of these miserable ones." 1

Inevitably the seventeenth-century dévots saw poverty and social violence in the setting of a debased "nature" rather than as concrete expressions of a specific social and political order. The destitute might be seen as the beloved of Christ, or fomenters of disorder, or both; but in any event it was impossible to regard them as a necessary product of a backward agriculture, economic localism, a parasitical fisc, and a predatory military policy - that is, of the very society which assured the upper-class dévots of "condition" and prestige. The social projects of this privileged religious elite betray significant departures from the medieval attitude to the poor, chiefly in a certain bureaucratic rationality; but ultimately the schemes of control and confinement reveal an ascetic orientation oblivious of social needs and of social change. The general hospitals and similar good works obeyed the limits marked out by the pessimistic spirituality of the French Counter Reformation. According to Cardinal Pierre de Bérulle (1575-1629), whose influence permeated the Company, the beginning of true religion was the recognition of the "vileness" and "nothingness" of

1 L'Hospital Général de Paris, p. 2. 
the self. Berullian mysticism taught self-abnegation and the adoration of an infinitely distant God. ${ }^{1}$ The Berullian dévots' projects of charity and social discipline were spiritualized in the sense that they were held to be, properly, the extension of personal ascetism. To leaders and inspirers of the Company of the Holy Sacrament like the mystic Gaston de Renty and J. J. Olier (founder of the famous seminary of Saint Sulpice) good works of charity were ultimately means toward the individual's spiritual perfection. The care of the vermin-ridden, brutalized, infected poor required the Christian to overcome his "natural" feelings of pride and revulsion. Good works were triumphs over the flesh. Olier's attention to the sick went far beyond the bounds of rational or even humane charity, and involved incredible, if not pathological, acts of self-mortification. ${ }^{2}$ Renty's work for the poor was also profoundly ascetic. An aristocrat and former soldier, he accustomed himself to take only one meal a day and to perform menial labors for mendicants. Usually he dined with poor men at his table, serving them with his own hands. ${ }^{3}$ Among these "saints bommes" of the Counter-Reformation, however, self-abasement did not conflict with organized and collective effort against disorder. Olier led the campaign against popular license in the faubourg St. Germain. Renty was a practical man, skilled as engineer, pharmacist, mechanic, ${ }^{4}$ and above all the Company's cutstanding leader during its most active and expansive period. For him private asceticism flowed into the activism of organized charity - just as in Berullian theology the radical nothingness of the self, the "nudity" of the soul, led to "respect", "adoration", and the "order" of a magnificent ritual religion. The imitation of Christ demands that good works proceed from selfmortification, that action be continuous with introspection and prayer. This conception of charity created the society of the Rentys, Oliers, Bossuets, and Lamoignons. It linked the zealot with the organized group, fervor with piety, asceticism with order. Secrecy itself - and the elaborate measures to protect it - which so greatly enhanced the power of the dévots' vast apparatus of virtue, was regarded by the founders of the Company as an ascetic practice, for

\footnotetext{
1 A convenient selection of Bérulle's spiritual writings is G. Rotureau's Le Cardinal de Bérulle, opuscules de piété (Paris, 1944). The best study of the man and his doctrine is $\mathrm{J}$. Dagens, Bérulle et les origines de la restauration catholique (N. p. , 1952).

${ }^{2}$ Faillon, Vie de M. Olier (Paris, 1873 ), I, pp. 54-56.

3 He also used a hair shirt, an iton belt with sharp studs to torment the flesh, and a heavy bronze crucifix carried around the neck and equipped with nails for the same purpose. It took the visionary, Sister Marguerite of the Holy Sacrament (of the Carmel at Beaune), herself a noted ascetic, to persuade Renty to relax these austerities somewhat (J. B. SaintJure, Vie de Monsieur de Renty [Paris, 16,2 ] p. 50).
}

4 Allier, Cabale, pp. I I3, I1 7, I 22-23; Saint-Jure, op. cit., pp. I53-54. 
they held that anonymity worked against the "hateful self", countering pride and ambition in works of charity. 1 Thus the impulse to selfabnegation became the basis of a social asceticism in which hatred of the self fed a revulsion from "disorder", and in which help to the suffering, since it served "higher" purposes, had to be kept within strict confessional limits. ${ }^{2}$ The Company's bureaucratic, disciplinarian tendency, its passion for religious decorum, its flair for systematic and rational means derived, not from new needs or from a rational program or conception of society, but rather from ascetic impulses turned in a socially repressive direction and colored by a profound conformism to the existing order. ${ }^{3}$

There was a side of the Berullian doctrines which emphasized "respect", "civility" toward God, and hieratic authority. Bossuet as court preacher exemplifies this classic and decorous Counter-Reformation. The official prelate par excellence, he was in his early years an active member of the Company of the Holy Sacrament. To him its organized projects were sanctified and majestic. He regarded the General Hospital as a spiritual edifice:

"Go to this hospital; venture a small distance beyond the city, and regard this new city which has been built for the poor, the asylum of all the miserable, the bank of heaven, the common means offered to all to insure their welfare and to multiply it by a celestial usury."4

This metaphorical quantification of the idea of grace was not accidental. It expressed widely prevalent attitudes toward good works

1 "De l'Esprit de la Compagnie du Saint-Sacrement", No. ıo(Annales, p. I95).

2 Among the disorders which the Company combatted most vigorously for over a generation was the "scandal" of the exercise of "the so-called reformed religion". In the meeting of November 18 , 1655 , on the eve of the foundation of the General Hospital of Paris, "It was proposed that the Huguenot hospital in the parish of Saint-Etienne du Mont be destroyed..." (Annales, p. 154).

- In his Considerations Chrétiennes et pratiques sur le dessein de Dieu dans l'institution de la société civile - one of the rare expressions of the social thought of the French Counter Reformation - J.-J. Olier held that men are divided and separated from each other by original sin, but brought together by civil society. "For if the rich person cannot live without being served, and without having a number of poor who assist him and give him their labor: the poor person on his side cannot live if the rich man does not give him sustenance and save him from his extremity." Since all of this is arranged through Divine Providence, when we receive goods from a merchant it should be "with thanks and obligation toward God..." The merchants should also feel the spirit of the master "who has chosen them for this ministry of his mercy and his love..." We should act with charity "in these encounters" since God acts with charity to all, giving each his own (reprinted in Faillon, op. cit, , 11, pp. 405-407).

4 Oeuvres, (Paris, I 852 ), II, p. 575. 
which had promoted and sustained the organized social action of the Counter-Reformation. These attitudes permitted the kind of rigorous, impersonal approach to popular license and indiscipline seen in the General Hospital's initial regime - the barracks-like atmosphere, the severance of personal bonds between donor and recipient, and, in effect, the prevention of any affective identification with the poor, save abstractly, "in Christ", or in the extraordinary acts of rare mystics. Despite the government's growing suspicion of the Company of the Holy Sacrament as a cabal of plotting aristocrats (a suspicion which was, in any event, largely erroneous) its social projects were complementary to the emerging methods of absolutist rule. Bossuet's praise of the General Hospital reflects his association with the devots in the I650's; it also echoes his own conformist dispositions to the established order, his hieratic reverence for royal authority, his efforts to establish a moral unity between the hierarchies of the Gallican Church and the aristocratic monarchy of Louis XIV.

The social attitudes which fostered the characteristically seventeenthcentury mixture of charity and repression were not peculiar to the religious elite, but were shared by the agents of the monarchy and by the cultivated classes generally. The French Counter Reformation belongs to an iron age of violence and mass deprivation. French classical culture and the historiographic tradition which celebrates it conceal the harsh realities of the time by ignoring them. (La Bruyère is a rule-proving exception.) The typifying, elevating tendency of classic literature, its very social abstractness, suggest the existence of an underworld of oppression, famine, license, and revolt, beyond discussion. The dramatists, memorialists, the writers of moral maxims reveal a common remoteness from the downtrodden and from ordinary humanity which is affective as well as intellectual. This remoteness was politically and culturally sanctified in the reign of Louis XIV ${ }^{1}$ but its moral basis had been created in the "age of saints". The vigilantism and repression which dominated the rational crusade were inspired by a hatred of the self. Social disorder was man's concupiscence writ large. The need of a constant and callous repression of the natural instincts constituted the basis and limit of religious projects of social discipline in the seventeenth century.

It is true that the semi-penal confinement of indigents was a general trend in seventeenth-century Europe and that the French schemes for general hospitals were probably influenced by the famous house of

\footnotetext{
1 The highly repressive criminal ordinance of 1670 retained torture, but said nothing of methods. Pussort maintained that the description of torture "would be indecent in an ordinance" (Lavisse, Hist. de France, VII, pt. I, p. 292.)
} 
correction in Amsterdam, ${ }^{1}$ possibly also by the English "Bridewells". Nevertheless, social conditions in France were different from those in the Protestant countries and so, also, were the prevailing motives. The Dutch and English houses of correction were basically responses to a rising social demand for disciplined labor - needs which made idleness costly as well as immoral (and which made the callous brutality of Tudor legislation against vagabonds not so much backward as irrelevant). In France the pace of economic advance was slower, agriculture less developed; moreover, mercantile and manufacturing interests were much less assertive politically and socially. The initiative in schemes of "improvement" came, not from municipal oligarchies or other groups closely associated with trade or production, but chiefly from a religious elite drawn from the privileged orders - beneficed clergy, holders of venal offices, and nobles and therefore dependent for income on the given socio-political system, that is, on political position rather than economic activity. These circumstances compose the background of the dévots' social action. They help to explain the fact that the work of inmates was not a primary concern of the sponsors of the general hospitals, being subordinate to the concern for intramural discipline. The conservative religious outlook of the dévots also prevented their projects of incarceration from developing into more strictly penal institutions (like the eighteenth-century dépotts de mendicité) or, on the other hand, from reverting completely to traditional charities of the type of the medieval almshouse - which had maintained small numbers, at times rather generously, and never penally. Moreover, in the plans of confinement which survive from the seventeenth century there is, despite a certain flair for system and method, little evidence of a concrete knowledge of - or, indeed, of much curiosity about - the actual circumstances and ramifications of poverty and mendicity. It is as if the concern with the poor led inward - to the place of confinement, to the soul, rather than outward to the social order. (The enormous modern literature on mendicity and poverty, fundamentally secular in its attention to social causation, begins in the eighteenth century.) For all this, the religious movement for the confinement of mendicants forms a significant chapter in the history of French absolutism, revealing the diversity of motive behind the institutions of mercantilism and public order, and suggesting also, perhaps, the social and historical limitations of these institutions.

1 During the middle of the seventeenth century the members of the Company of the Holy Sacrament of Lyon discussed the idea of enclosing sturdy beggars in public workshops "in order to make them labor as is done in Holland" (Guigue, op. cit., p. I I8). 